\title{
Participatory constraint analysis regarding the adoption of IPM technologies in pointed gourd cultivation: An empirical study
}

\author{
Sarthak Chowdhury and Prabuddha Ray \\ Department of Agricultural Extension, Agricultural Economics and Agricultural Statistics, Palli Shiksha Bhavana \\ (Institute of Agriculture), Sriniketan, Visva-Bharati, P.O.- Sriniketan, Dist. - Birbhum, Pin:- 731 236, West Bengal, \\ India and Department of Agricultural Extension, Agricultural Economics and Agricultural Statistics, Palli Shiksha \\ Bhavana (Institute of Agriculture), Sriniketan, Visva-Bharati, P.O.- Sriniketan, Dist. - Birbhum, Pin:- 731 236, West \\ Bengal, India
}

\begin{abstract}
The empirical study revealed that among the various types of constraints (as perceived by the respondents) regarding the adoption of IPM technologies in the Pointed Gourd (Trichosan thes dioica Roxb.) production, the lack of knowledge of the respondents about the Economic Threshold Limit (ETL) concept ranked first closely followed by the lack of knowledge of the respondents regarding the bio-pesticides (under the category of knowledge and information constraints) in second position, the lack of knowledge of the respondents about the Integrated Pest Management (IPM) techniques ranked third position, closely followed by lack of training of the respondents on the proper use of pesticides in the fourth position.

The result also showed that among six numbers of different categories of perceived constraints, knowledge and information constraints with a rank score of 2769 enjoyed first rank position, distantly followed by administrative and managerial constraints (with a rank score of 1586) in the second position, technological and communication constraints with a rank score of 1249 in the third position, socio-economic constraint (rank score of 828) in the fourth position.
\end{abstract}

Keywords: Adoption of IPM techniques, Constraints, Categories of constraints

\section{Introduction}

Integrated Pest Management (IPM) is a scientific paradigm (Perkins, 1982) which is now of global significance. Its basic concern is with designing and implementing pest management practices that meet the goals of farmers, consumers and governments in reducing pest loses while, at the same time, safeguarding against the longer term risk of environmental pollution, hazards to human health, and reduced agricultural sustainability.

While the philosophy and ideas of IPM are now widely accepted in the political and scientific arena, the practical implementation of IPM has proved far more difficult to achieve. Over two decades, attempts to develop and disseminate IPM technologies in the developing countries have met with limited success (Kiss and Meerman - 1991, Yudelman et al. - 1998). A number of reasons for this limited success were identified by the different researchers viz.:

- Insufficient extension resource to serve the needs of the farmers who wish to employ IPM (Brader, 1979).

- The need for more emphasis on farmers training to get the IPM message across (Kenmore, 1987).

Commercial pressures on farmers to use pesticides, and the idea that pesticides companies disrupt IPM research and implementation activities could be important in specific cases. We believe that a more important reason for a lack of IPM adoption is that the IPM 'product' is often not appropriate to farmers' need (Norton - 1976, Goodell - 1984). Farmers may perceive IPM as too complex, too expensive, too risky, and just not appropriate to their farming system.

In this regard, we must keep in mind that IPM was first developed in response to the environmental concerns about the abuse or over use of the chemical pesticides associated with the input-intensive agricultural systems of the developed countries. The traditional approach regarding the IPM technology development was to develop pest and disease control alternatives to reduce or eliminate the use of chemical pesticides. Here, the role of the agricultural extension system was to transfer and disseminate these technologies and practices directly to the farmers (Morse and Buhler, 1997). More recently, alternative approaches have been evolved for the small-scale farming systems of the developing countries. These approaches seek to combine indigenous farmer knowledge with scientific knowledge of cropping systems and pests to develop site appropriate IPM systems. Variously labeled as ecological or sustainable IPM (Schwab - 1995, Mangam and Mangam - 1998), these approaches are often described as being knowledge-intensive (Morse and Buhler, 1997). This new approach regarding IPM technologies required enhance knowledge and understanding of the small farmers regarding the biological factors and ecological interactions (Dent, 1995). 
So, it is of utmost necessity for the scientific community to find out and analyze the field level constraints (as perceived by the farmers) in the adoption of IPM technologies especially in the vegetable cultivation in the third world countries where excessive and indiscriminate use of the pesticides were reported by various researchers like Rashid et al. (2003), IPM DANIDA Project (2004), Kim and Park (2005), Baral et al. (2006) etc. Here a participatory constraint analysis method was utilized where the respondent farmers were asked to mention the constraints, place the constraints in a four point continuum and rank them following the complimentary mix of participatory as well as formal approach as developed by Hubert (1991), NCAER (1993), Shah (1993), Rajaratnam et al. (1993) and Malik and Edwards (1993/1994).

\section{Objectives of the study}

(1) To study the field level constraints (as perceived by the respondents) in the adoption of IPM technologies on the selected vegetable in a participatory approach method,

(2) To examine extent or magnitude of these field level constraints in the adoption of IPM technologies on the selected vegetable category wise and

(3) To suggest some ameliorative measures based on findings.

\section{Materials and Methods}

Two way direct communications is a "must" to achieve good rapport in any research work, which involves farmers as the unit of study. Keeping these in view, researchers' own state namely, West Bengal in India was selected for the present study.

The state of West Bengal has nineteen districts. Among these districts, the district of Bardhaman is one of the most agriculturally advanced and prosperous district of the state apart from being the home district of the present investigators. So, this district was purposively selected for the present study.

The district of Bardhaman has thirty one (31) Community Development (CD) Blocks. Among these CD Blocks, the Katwa- I Block was purposively selected for the present study, because the soil of Katwa-I Block was conducive for vegetable cultivation. This was supported by the fact that nearly 1000 hectares of land were under the vegetable cultivation in the winter season in the Katwa-I Block in the year 2005-06 (Source :- Department of Agriculture, Govt. of West Bengal). The production of Pointed Gourd (Trichosan thes dioica Roxb.) topped the list of the production of the summer vegetables in the selected CD Block. So, Pointed Gourd was selected for the present study.

This CD Block also consumed a large amount of pesticides for plant protection purposes. The Katwa-I Block consumed nearly 8000 litres of pesticides in the year of 2005-06. Apart from these facts, the KatwaI Block was home block of one of the present investigators.

All the villages, eighteen (18) in numbers falling under the five (5) kilometers radius of Katwa Town were selected for the present study. As these villages have sizeable population who grew Pointed Gourd commercially in more than 0.33 acre or 0.57 hectare or 1 bigha of farm land were taken into consideration for the present study. At present 150 such farmers were there. So, all the 150 vegetable growers were selected as the sample population of the present study.

The data was collected with the help of a structured question-schedule developed for the study and through the personal interview method. The data was collected from June, 2006 to May, 2007 at the selected villages. After completion of data collection, thorough checking was made on the filled up schedules and then the schedules were numbered. The numbered schedules were tabulated according to their numbers.

Following the Participatory Approach as mentioned by Hubert (1991), at first the respondents noted the constraints regarding the adoption of IPM techniques according to their own wishes. Then formal method was adopted to measure the degree of constraints as experienced by the respondents in relation to the adoption of IPM techniques and the respondents were asked to indicate on a four point continuum about the extent to which each constraint was perceived as crucial factor for adoption of IPM technologies on the selected vegetables. The scoring procedure was as follows:

$\begin{array}{ccc}\text { SI. No. } & \text { Category } & \text { Score } \\ 1 . & \text { High } & 3 \\ 2 . & \text { Medium } & 2 \\ 3 . & \text { Low } & 1 \\ 4 . & \text { Not at all } & 0\end{array}$


The rank score of each individual constraint as experienced by the respondents in relation to the adoption of IPM technologies was calculated by multiplying the frequencies with the respective weights of that particular constraint and later adding them up. On the basis of their respective rank scores, each constraint as experienced by the respondents in relation to the adoption of IPM technologies was rankordered. The various constraints as experienced by the respondents in relation to the adoption of IPM technologies were categorized with the help of the past studies conducted by Gomez (1977), Lal (1977), Swaminathan (1978), Mahapatra (1984), Tantray and Nanda (1991) and Singh et al. (1993).

\section{Results and Discussion}

\section{Field level constraints experienced by the respondents regarding the adoption of the IPM technologies in the Pointed Gourd cultivation}

The ranking (both category-wise ranking and overall ranking) of various field level constraints as perceived by the respondents regarding the adoption of the IPM technologies in Pointed Gourd cultivation was given in Table 1.

From the Table 1, it became clear that among the socio-economic constraints as perceived by the respondents regarding the adoption of IPM technologies in the Pointed Gourd cultivation, lack of consmopoliteness of the respondents held the first rank position followed by lack of financial resources of the respondents, lack of education of the respondent, small size of land holding of the respondent, age of the respondent and gender of the respondents. This was apparently because of more the cosmopoliteness of the respondents, more they would have exposures to various sources of information which would encourage the respondents regarding the adoption of IPM technologies for the Pointed Gourd production.

Table 1 depicted the picture that revealed that among the infrastructural constraints lack of preservation and cold-storage facilities for the selected vegetable enjoyed the first position followed by the lack of communication and transport which enjoyed the second position. Lack of irrigational facilities held the third rank position followed by the lack of the vegetable market in the fourth rank position. Among the infrastructural constraints, lack of preservation and cold-storage facilities enjoyed the first position might be because of the fact without proper preservation facilities, the Pointed Gourd growers were under pressure to sell the harvested Pointed Gourd crops immediately which in turn encouraged the Pointed Gourd growers to apply the pesticides more for increased level protection from the pests and vis-à-vis increased yield of the Pointed Gourd crops and thus the farmers tended to dissociate themselves from the adoption of IPM technologies in the Pointed Gourd cultivation.

Table 1 clearly showed us that among the situational constraints regarding the regarding the adoption of IPM technologies in the Pointed Gourd production, average distance between the fragments of the cultivated land of the respondents held the first position, closely followed by fragmentation of the cultivated land of the respondents. Fragmentation of the cultivated land of the respondents and lack of supply of the pesticides in the market at the right time enjoyed the third and fourth positions respectively.

From the Table 1, it became clear that among technological and communication constraints as perceived by the respondents, the inadequate / complicated description regarding the precautions to be taken in the case of toxicity related accidents in the written materials kept in the containers of pesticides enjoyed the first rank position, followed by the lack of proper Integrated Pest Management (IPM) technologies for the Pointed Gourd crops in the second position. The quality of the printing of the written materials kept in the containers of the pesticides was in the third position and the colour used in the written materials kept in the containers of pesticides enjoyed the fourth position. The fact that given description regarding the precautions to be taken in the case of toxicity related accidents in the written materials kept in the containers of pesticides enjoyed the first rank position might be due to the cause that unclear, complicated, written in highly technical way of writing and below quality descriptions would compel the respondents to use the pesticides without any precaution in the Pointed Gourd cultivation.

From the Table 1, it became clear that among the knowledge and information constraints as perceived by the respondents regarding the adoption of IPM technologies, the lack of knowledge of the respondents about the Economic Threshold Limit (ETL) concept of the Pointed Gourd crops held the first rank position, closely followed by the lack of knowledge of the Pointed Gourd growers regarding the bio-pesticides in the second position which was closely followed by the lack of knowledge of the respondents about the 
Integrated Pest Management (IPM) techniques for the cultivation of the Pointed Gourd crops in the third position. The lack of proper information on the judicious use of pesticides was in the fourth position. The fact that the lack of knowledge of the respondents (vegetable growers) about the Economic Threshold Limit (ETL) concept of the Pointed Gourd crops held the first rank position among the knowledge and information constraints might be due to the cause that without the knowledge about the Economic Threshold Limit (ETL) concept of the Pointed Gourd crop, the respondents were prone to use the chemical pesticides more in numbers, frequency and quantity in the Pointed Gourd cultivation than suggested by the IPM experts.

From the Table 1, it was apparent that among the administrative and managerial constraints as perceived by respondents lack of training of the respondents on the IPM technologies enjoyed the first position, closely followed by non-availability of extension personnel in time in the second position and distantly followed by cheating by the sales agents and dealers of pesticide companies. In the fourth position lack of loan sanctioning mechanism for the vegetable growers for the cultivation of the Pointed Gourd crops was there. Among the administrative and managerial constraints, lack of training of the vegetable growers on the IPM technologies in the Pointed Gourd production enjoyed the first position because of the fact that without proper training of the respondents regarding the IPM technologies, the respondents would be likely prone to misuse of pesticides in the Pointed Gourd production.

Table 1 revealed that among all the various types of constraints perceived by the respondents regarding the adoption of IPM technologies in the Pointed Gourd production, the lack of knowledge of the respondents (vegetable growers) about the Economic Threshold Limit (ETL) concept of the Pointed Gourd crops (under the category of knowledge and information constraints) enjoyed the first rank position closely followed by the lack of knowledge of the respondents regarding the bio-pesticides (under the category of knowledge and information constraints) in second position, the lack of knowledge of the respondents about the Integrated Pest Management (IPM) techniques for the cultivation of the Pointed Gourd crops (under the knowledge and information constraints category) enjoyed third position, closely followed by lack of training of the vegetable growers on the proper use of pesticides in the Pointed Gourd production (under category of administrative and managerial constraints) in the fourth position. It proved that the lack of knowledge of the respondents (vegetable growers) about the Economic Threshold Limit (ETL) concept of the Pointed Gourd crops, lack of knowledge of respondents regarding the bio-pesticides, the lack of knowledge of the respondents about the Integrated Pest Management (IPM) techniques for the cultivation of the Pointed Gourd crops and lack of training of the vegetable growers on the IPM technologies in the Pointed Gourd production put the most formidable hurdle before the respondents regarding the adoption of IPM technologies in the Pointed Gourd production.

\section{Analysis of category wise field level constraints experienced by the respondents regarding the adoption of the IPM technologies in the Pointed Gourd cultivation}

Table 1 and 2 clearly showed us that among six numbers of different categories of perceived constraints regarding the adoption of IPM technologies in Pointed Gourd cultivation, knowledge and information constraints with a rank score of 2769 enjoyed first rank position, distantly followed by administrative and managerial constraints (with a rank score of 1586) in the second position, technological and communication constraints with a rank score of 1249 in the third position, socio-economic constraint (rank score of 828) in the fourth position and it was interesting to note that situational constraints enjoyed the last position with only 589 rank score. The fact that the knowledge and information constraints held the highest position among different categories of constraints might because of the reason that the respondents had very poor level of knowledge regarding the adoption of IPM technologies in Pointed Gourd cultivation as well as they had very poor access to the sources of the information regarding the adoption of IPM technologies which was already indicated in the different results obtained in the earlier sections of this paper. The above results also showed us that various administrative and managerial lacunae (incompetent extension services, inadequate monitoring of the markets etc.) on the part of the central and state governments contributed to a great extent to the low level of adoption of IPM technologies in Pointed Gourd cultivation among the respondents. The results also revealed that the respondents were technologically ill equipped as well as there were various problems in the communication processes with the Pointed Gourd farmers to adopt the IPM technologies in their Pointed Gourd cultivation. 
Table 1. Ranking of various constraints (as perceived by the respondents) regarding the proper use of pesticides in the Pointed Gourd cultivation

\begin{tabular}{|c|c|c|c|c|}
\hline $\begin{array}{l}\text { Sl. } \\
\text { No. }\end{array}$ & Category of constraints & $\begin{array}{l}\text { Rank } \\
\text { score }\end{array}$ & $\begin{array}{l}\text { Rank position within a } \\
\text { particular category }\end{array}$ & $\begin{array}{l}\text { Overall rank } \\
\text { position }\end{array}$ \\
\hline & A. Socio-economic Constraints & & & \\
\hline 01. & Lack of cosmopoliteness of the vegetable growers & 306 & $\mathrm{I}$ & $\mathrm{V}$ \\
\hline 02. & Lack of financial resources of the vegetable growers & 195 & II & $\mathrm{XVI}$ \\
\hline 03. & Lack of education of the vegetable growers & 158 & III & XXII \\
\hline 04. & Small size of land holding of the vegetable growers & 150 & IV & $\mathrm{XXV}$ \\
\hline 05. & Age of the vegetable growers & 14 & $\mathrm{~V}$ & XXXXV \\
\hline \multirow[t]{3}{*}{06.} & Gender of the vegetable growers & 05 & $\mathrm{VI}$ & $\overline{X X X X V I}$ \\
\hline & Total of Category & 828 & & IV \\
\hline & B. Infrastructural Constraints & & & \\
\hline 07. & $\begin{array}{l}\text { Lack of preservation and cold-storage facilities for the selected } \\
\text { vegetables }\end{array}$ & 270 & $\mathrm{I}$ & VII \\
\hline 08. & Lack of communication and transport & 97 & II & XXXVIII \\
\hline 09. & Lack of irrigational facilities & 60 & III & XXXXI \\
\hline 10. & Lack of vegetable market & 57 & IV & XXXXII \\
\hline \multirow[t]{3}{*}{11.} & Lack of proper plant protection implements & 52 & V & XXXXIII \\
\hline & Total of category & 536 & & VI \\
\hline & C. Situational Constraints & & & \\
\hline 12. & $\begin{array}{l}\text { Average distance between the fragments of the cultivated land of } \\
\text { the vegetable growers }\end{array}$ & 173 & $\mathrm{I}$ & XVII \\
\hline 13. & Lack of mutual co-operation among the vegetable growers & 169 & II & XVIII \\
\hline 14. & Fragmentation of the cultivated land of the vegetable growers & 138 & III & XXVIII \\
\hline 15. & Lack of supply of the pesticides in the market at the right time & 109 & IV & $\mathrm{XXXV}$ \\
\hline \multirow[t]{3}{*}{16.} & Topography of land & 51 & V & XXXXIV \\
\hline & Total of category & 640 & & $\mathrm{~V}$ \\
\hline & D. Technological and Communication Constraints & & & \\
\hline 17. & $\begin{array}{l}\text { Inadequate / complicated description regarding the precautious to } \\
\text { be taken in the case of toxicity related accidents in the written } \\
\text { materials kept in the containers of pesticides }\end{array}$ & 236 & I & VIII \\
\hline 18. & $\begin{array}{l}\text { Lack of proper Integrated Pest Management (IPM) technologies } \\
\text { for the selected vegetables }\end{array}$ & 212 & II & XIV \\
\hline 19. & $\begin{array}{l}\text { The quality of the printing of the written materials kept in the } \\
\text { containers of the pesticides }\end{array}$ & 167 & III & $\mathrm{XIX}$ \\
\hline 20. & $\begin{array}{l}\text { The colour used in the written materials kept in the containers of } \\
\text { pesticides }\end{array}$ & 161 & IV & $\mathrm{XXI}$ \\
\hline 21. & $\begin{array}{l}\text { The quality of the pictures of the pests used in the written } \\
\text { materials kept in the containers of the pesticides }\end{array}$ & 151 & $\mathrm{~V}$ & XXIV \\
\hline 22. & $\begin{array}{l}\text { Size of the letters of the written materials kept in the pesticide } \\
\text { containers }\end{array}$ & 114 & VI & XXXIII \\
\hline 23. & $\begin{array}{l}\text { Language of the written materials kept in the containers of the } \\
\text { pesticides }\end{array}$ & 105 & VII & $\mathrm{XXXVI}$ \\
\hline \multirow[t]{3}{*}{24.} & $\begin{array}{l}\text { The quality of the various diagrammatic representations used in } \\
\text { the written materials kept in the containers of the pesticides }\end{array}$ & 103 & VIII & $\overline{X X X V I I}$ \\
\hline & Total of category & 1249 & & III \\
\hline & E. Knowledge and Information Constraints & & & \\
\hline 25. & $\begin{array}{l}\text { Lack of knowledge of the respondents (vegetable growers) about } \\
\text { the Economic Threshold Limit (ETL) concept of the selected } \\
\text { vegetables }\end{array}$ & 330 & $\mathrm{I}$ & $\mathrm{I}$ \\
\hline 26. & $\begin{array}{l}\text { Lack of knowledge of the vegetable growers regarding the bio- } \\
\text { pesticides }\end{array}$ & 324 & II & II \\
\hline 27. & $\begin{array}{l}\text { Lack of knowledge of the respondents about the Integrated Pest } \\
\text { Management (IPM) techniques for the cultivation of the selected } \\
\text { vegetables }\end{array}$ & 323 & III & III \\
\hline 28. & Lack of proper information on the judicious use of pesticides & 233 & IV & $\mathrm{X}$ \\
\hline 29. & $\begin{array}{l}\text { Lack of knowledge of the vegetable growers regarding the process } \\
\text { of diagnosis of the attacking pests }\end{array}$ & 228 & V & $\mathrm{XI}$ \\
\hline 30. & $\begin{array}{l}\text { Lack of information regarding the pesticide application on the } \\
\text { selected vegetables }\end{array}$ & 201 & $\mathrm{VI}$ & $\mathrm{XV}$ \\
\hline 31. & $\begin{array}{l}\text { Lack of knowledge of the respondents regarding the proper } \\
\text { handling procedure of the pesticides }\end{array}$ & 157 & VII & XXIII \\
\hline 32. & $\begin{array}{l}\text { Lack of knowledge of the vegetable growers regarding the proper } \\
\text { pesticide application procedure on the selected vegetables }\end{array}$ & 145 & VIII & $\mathrm{XXVI}$ \\
\hline 33. & $\begin{array}{l}\text { Lack of knowledge of the vegetable growers about the ideal dose } \\
\text { of the applied pesticides in the cultivation of the selected } \\
\text { vegetables }\end{array}$ & 141 & IX & XXVII \\
\hline
\end{tabular}


Table 1 Contd.

\begin{tabular}{|c|c|c|c|c|}
\hline $\begin{array}{l}\text { Sl. } \\
\text { No. }\end{array}$ & Category of constraints & $\begin{array}{l}\text { Rank } \\
\text { score }\end{array}$ & $\begin{array}{l}\text { Rank position within a } \\
\text { particular category }\end{array}$ & $\begin{array}{l}\text { Overall rank } \\
\text { position }\end{array}$ \\
\hline 34. & $\begin{array}{l}\text { Lack of knowledge of the vegetable growers regarding the proper } \\
\text { pesticide storage procedure to be maintained by the vegetable } \\
\text { growers }\end{array}$ & 137 & $\mathrm{X}$ & $\mathrm{XXIX}$ \\
\hline 35. & $\begin{array}{l}\text { Lack of knowledge of the vegetable growers regarding the proper } \\
\text { way of disposing off of the date expired, unused pesticide } \\
\text { containers }\end{array}$ & 136 & $\mathrm{XI}$ & $\mathrm{XXX}$ \\
\hline 36. & $\begin{array}{l}\text { Lack of Knowledge of the vegetable growers regarding the ideal } \\
\text { time of the day when the pesticide should be applied }\end{array}$ & 129 & XII & $\mathrm{XXXI}$ \\
\hline 37. & $\begin{array}{l}\text { Lack of knowledge of the vegetable growers regarding the } \\
\text { precautions to be taken when the pesticide application was on }\end{array}$ & 113 & XIII & XXXIV \\
\hline 38. & $\begin{array}{l}\text { Lack of knowledge of the vegetable growers regarding proper way } \\
\text { of disposing off of the empty containers of the pesticides }\end{array}$ & 87 & $\mathrm{XIV}$ & XXXIX \\
\hline \multirow[t]{3}{*}{39.} & $\begin{array}{l}\text { Lack of knowledge of the vegetable growers regarding the ideal } \\
\text { crop stage for the pesticide application }\end{array}$ & 85 & $\mathrm{XV}$ & $\mathrm{XXXX}$ \\
\hline & Total of category & 2769 & & $\mathrm{I}$ \\
\hline & F. Administrative and Managerial Constraints & & & \\
\hline 40. & $\begin{array}{l}\text { Lack of training of the vegetable growers on the proper use of } \\
\text { pesticides }\end{array}$ & 319 & I & IV \\
\hline 41. & Non-availability of extension personnel in time & 296 & II & VI \\
\hline 42. & $\begin{array}{l}\text { Malpractices by the sales agents and dealers of pesticide } \\
\text { companies }\end{array}$ & 235 & III & IX \\
\hline 43. & $\begin{array}{l}\text { Lack of loan sanctioning mechanism for the vegetable growers for } \\
\text { the cultivation of the selected vegetables }\end{array}$ & 226 & IV & $\overline{X I I}$ \\
\hline 44. & $\begin{array}{l}\text { Lack of the agricultural extension mechanisms for the selected } \\
\text { vegetables }\end{array}$ & 218 & $\mathrm{~V}$ & XIII \\
\hline 45. & $\begin{array}{l}\text { Problems created by the middlemen in the wholesale or the retail } \\
\text { vegetable market }\end{array}$ & 164 & $\mathrm{VI}$ & $\mathrm{XX}$ \\
\hline \multirow[t]{2}{*}{46.} & $\begin{array}{l}\begin{array}{l}\text { Adulteration of the pesticides by the dealers of pesticide } \\
\text { companies }\end{array} \\
\end{array}$ & 128 & VII & XXXII \\
\hline & Total of category & 1586 & & II \\
\hline
\end{tabular}

Table 2. Distribution of various categories of constraints as perceived by the respondents regarding the proper use of pesticides in the Pointed Gourd cultivation

\begin{tabular}{|l|l|c|c|c|}
\hline SI. No. & Various categories of constraints & $\begin{array}{c}\text { Total Rank } \\
\text { Score }\end{array}$ & Percentage & $\begin{array}{c}\text { Rank } \\
\text { position }\end{array}$ \\
\hline 01. & Knowledge and Information constraints & 2769 & 36.40 & $\mathrm{I}$ \\
\hline 02. & Administrative and managerial constraints & 1586 & 20.85 & $\mathrm{II}$ \\
\hline 03. & Technological and Communication constraints & 1249 & 16.42 & $\mathrm{III}$ \\
\hline 04. & Socio-economic constraints & 828 & 10.88 & $\mathrm{IV}$ \\
\hline 05. & Situational constraints & 640 & 08.40 & $\mathrm{~V}$ \\
\hline 06. & Infrastructural constraints & 536 & 07.05 & $\mathrm{VI}$ \\
\hline & Total & 7608 & 100.00 & \\
\hline
\end{tabular}

Table 2 showed us that among various categories of constraints, knowledge and information constraints had highest percentage of 36.40 percent, distantly followed by administrative and managerial constraints (20.85 percent) in the second position and technological and communication constraints (16.42 percent) in the third position respectively. It was interesting to note that the infrastructural constraints held the lowest position with only 07.05 percentage points. The above table clearly depicted a picture that the biggest constraint before the respondents was knowledge and information constraints regarding the adoption of the IPM technologies in the Pointed Gourd cultivation. This meant that the respondents had very poor level of knowledge regarding the various aspects of the IPM technologies in the Pointed Gourd cultivation as well as they had very poor access to the sources of the information regarding the IPM technologies which was already indicated in the different results obtained in the earlier sections of the paper.

It was interesting to note that poor extension services, poor vigilance of the central and state governments on the pesticide market, inadequate and poorly governed vegetable markets etc. led the administrative and managerial constraints to the second position. 
The Tables 1 and 2 clearly depicted a picture that the third biggest constraint before the respondents was technological and communication constraint regarding the adoption of the IPM technologies in the Pointed Gourd production. This meant that the respondents were technologically ill equipped for adoption of the IPM technologies for the Pointed Gourd crops and the communication channel for making the respondents aware about the technical specifications and information regarding the IPM technologies was poorly developed and to some extent ineffective in nature.

The socio-economic constraints like lack of cosmopoliteness, lack of financial resources, lack of education, small size of land holdings etc. considerably affected the proper use of the pesticides by the respondents in the vegetable cultivation. As a result, socio-economic constraints came in the fourth position among the various categories of constraints regarding the adoption of the IPM technologies.

It was interesting to note that the infrastructural constraints came in last position with only 07.05 percentage points. This means that there were little grass-root level infrastructural constraints related to the farming operations in general and the Pointed Gourd cultivation in particular like lack of preservation and cold-storage facilities for the harvested Pointed Gourd crops, lack of communication and transport, lack of irrigational facilities, lack of Pointed Gourd market, lack of proper plant protection implements etc. posed little constraints to the respondents in relation to the adoption of the IPM technologies. This was a silver-line of hope among the otherwise bleak scenario.

\section{Conclusion}

Interpretation of the data on the constraints as experienced by the respondents regarding the adoption of the IPM technologies in the Pointed Gourd cultivation, revealed that lack of knowledge of the respondents (vegetable growers) about the Economic Threshold Limit (ETL) concept of the Pointed Gourd crops, lack of knowledge of respondents regarding the bio-pesticides, the lack of knowledge of the respondents about the Integrated Pest Management (IPM) techniques for the cultivation of the Pointed Gourd crops and lack of training of the vegetable growers on the IPM technologies in the Pointed Gourd production put the most formidable hurdle before the respondents regarding the adoption of IPM technologies in the Pointed Gourd production.

The present study showed us that among six numbers of different categories of perceived constraints regarding the adoption of IPM technologies in Pointed Gourd cultivation, knowledge and information constraints enjoyed first rank position, distantly followed by administrative and managerial constraints in the second position, technological and communication constraints in the third position, socio-economic constraint in the fourth position and it was interesting to note that situational constraints enjoyed the last position. The fact that the knowledge and information constraints held the highest position among different categories of constraints might because of the reason that the respondents had very poor level of knowledge regarding the adoption of IPM technologies in Pointed Gourd cultivation as well as they had very poor access to the sources of the information regarding the adoption of IPM technologies which was already indicated in the different results obtained in the earlier sections of this paper. The above results also showed us that various administrative and managerial lacunae (incompetent extension services, inadequate monitoring of the markets etc.) on the part of the central and state governments contributed to a great extent to the low level of adoption of IPM technologies in Pointed Gourd cultivation among the respondents. The results also revealed that the respondents were technologically ill equipped as well as there were various problems in the communication processes with the Pointed Gourd farmers to adopt the IPM technologies in their Pointed Gourd cultivation.

The above results depicted a picture that the biggest constraint before the respondents was knowledge and information constraints regarding the adoption of the IPM technologies in the Pointed Gourd cultivation. This meant that the respondents had very poor level of knowledge regarding the various aspects of the adoption of the IPM technologies in the Pointed Gourd cultivation as well as they had very poor access to the sources of the information regarding the adoption of the IPM technologies in the Pointed Gourd cultivation which was already indicated in the results obtained in the Results portion of this Paper.

It was interesting to note that poor extension services, poor vigilance of the central and state governments on the pesticide market, inadequate and poorly governed Pointed Gourd markets etc. led the administrative and managerial constraints to the second position. 
The present study clearly depicted a picture that the third biggest constraint before the respondents was technological and communication constraint regarding adoption of IPM technologies in the Pointed Gourd production. This meant that the respondents were technologically ill equipped for the adoption of IPM technologies for the Pointed Gourd crops and the communication channel for making the respondents aware about the technical specifications and information regarding the IPM technologies in the cultivation of the Pointed Gourd crops was poorly developed and to some extent ineffective in nature.

\section{Recommendation}

The evidence suggests that introducing IPM in South East Asia through the conventional transfer of technology oriented communication strategies simply do not work. The present study also revealed that the biggest constraint before the respondents was knowledge and information constraints regarding the adoption of the IPM technologies in the Pointed Gourd cultivation. So to achieve the widespread adoption of IPM techniques by the small and marginal as well as big and medium farmers of the developing countries, a new strategy should be put forward and implemented by all the concerned quarter of the society i.e. from the public sector extension agencies to the non-governmental organizations involved in the field of agriculture and the allied sectors. To be successful, the new strategy for spreading the IPM message should aim at:

(a) building the farmers' confidence about the IPM techniques,

(b) raising the decision making abilities of the farmers regarding the pest management techniques,

(c) facilitating action-research and participatory technology development regarding the pest management techniques,

(d) finding a common perception of pest management problems by the researches and the farmers,

(e) integrating local indigenous knowledge into the IPM paradigm,

(f) explaining the complexities and intrigues of the IPM technologies among the farming community,

(g) promoting farmer interactive, participatory extension approach regarding the IPM technologies,

(h) addressing groups of the farmers rather than the individuals in the IPM technologies,

(i) promoting a communication approach which would cultivate a common identity among the IPM farmers and trainers,

(j) exploring the salient and attractive points of the IPM techniques what is attractive to the farmers and

(k) training of the extension personnel and the trainers.

The above mentioned points were also emphasized by Schmidt et al. (1997). Van de Fliert and Matteson (1989) commented that seasonal farmers meetings and Village Development Societies might offer avenues for organizing farmers to set up collective IPM activities. Awareness enhancing and motivational messages delivered via traditional and mass media in support of an expanded Extension Service farmer training programme in Vegetable IPM could be expected to contribute to safer and more profitable vegetable pest control.

\section{References}

Baral, K., Roy, B.C., Rahim, K.M.B., Chatterjee, H., Mondal, D., Ghosh, D. and Talekar, N.S. 2006. Socio-economic Parameters of Pesticide Use and Assessment of Impact of an IPM Strategy for the Control of Eggplant Fruit and Shoot Borer in West Bengal, India - Technical Bulletin No. 37, AVRDC - The World Vegetable Center, Shanhua, pp. 2 - 3, 12 - $13,16$.

Brader, L. 1979. Integrated pest control in the developing world, Annual Review of Entomology, Vol. 24, pp. 225 - 254.

Dent, D. 1995. Integrated Pest Management, Chapman and Hall, London.

Gomez, K. A. 1977. On farm assessment of yield constraints: Methodological problems, Constraints to high yield on Asian rice farms: An interim report, IRRI, Philippines.

Goodell, G. 1984. Challenges to international pest management research and extension in the Third World: Do we really want IPM to work? Bulletin of the Entomological Society of America, Vol. 30, pp. 18 - 26.

Hubert, J.P. 1991. Comparing two methods for implementing Farming System Surveys in the Imbo Region of Burundi, $11^{\text {th }}$. FSR/E Symposium, $31^{\text {st }}$. October, 1991, Michigan State University.

IPM DANIDA. Project 2004. Pesticides-Health Survey: Data of 124 farmers in Chaiprakarn Chiang Mai, Thailand May 2004, IPM DANIDA 64, November, 2004, Thailand, pp. 3 - 10.

Kenmore, P.E. 1987. Crop loss assessment in a practical integrated pest control programme for tropical Asian rice. In P.S.Teng, ed. Crop Loss Assessment and Pest Management, American Phytopathological Society, pp. $225-241$. 
Kim, J. and Park, H. 2005. Slow Suicide: How Korean Farmers are poisoning themselves with Pesticides, PAN Asia and the Pacific, Penang, pp. 19, $23-28$.

Kiss, A. and Meerman, F. 1991. Integrated Pest Management in African Agriculture, World Bank Technical Paper 142, World Bank, Washington DC.

Lal, S. 1977. Increasing rice production under rainfed lowland situation, Indian Farming, Vol. XXXVI, No. 12 (3 - 7), March, 1977.

Mahapatra, I.C. 1984. Production constraints and future prospects of rice in eastern India, Proceedings of International Symposium on Natural Resource Management for Sustainable Agriculture, Vol. I, Organized by Indian Society of Agronomy, New Delhi.

Malik, H. and Edwards, R. 1993/94. Notes in Large Scale Wealth Ranking in West Pakistan: An Application by Action Aid, Pakistan.

Mangan, J. and Mangam, M. 1998. A comparison of two IPM training strategies in China: The importance of concepts of rice ecosystem for sustainable insect pest management, Agriculture and Human Values, Vol. 15, pp. $209-221$.

Morse, S. and Buhler, W. 1997. Integrated Pest Management: Ideals and Realities in Developing Countries, Boulder, Co. Lynne Rienner Publishersw.

National Council of Applied Economic Research (NCAER). 1993. Comparative Study of sample Survey and Participatory Rural Apprisal Methodologies with special reference to evaluation of national programme on improved chullah, New Delhi.

Norton, G.A. 1976. Analysis of decision making in crop protection, Agro-Ecosystems, Vol. 03, pp. 27 - 44.

Perkins, J.H. 1982. Insects, Experts and the Insecticide Crisis: the Quest for New Pest Management Strategies, Plenum Press, New York.

Rajaratnam, J., Ganeshan, C., Thaspian, H., Babu, N. and Abel, R. 1992. Validating Wealth Ranking of PRA and Formal Survey in Identifying the Rural Poor, RUHSA Department, Christian Medical College and Hospital, RUHSA Campus, Tamil Nadu.

Rashid, M.A., Alam, S.N., Rouf, F.M.A., and Talekar, N.S. 2003. Socio-economic Parameters of Eggplant Pest Control in Jessore District of Bangladesh- Technical Bulletin No. 29, AVRDC - The World Vegetable Center, Shanhua, pp. iii, 9, 13, 14, 23.

Schwab, A. 1995. Fear of harvest failure - the compelling force behind the worldwide use of pesticides. In A. Schwab, I. Jager, G. Stoll, R. Gorgen, S. Prexler-Schwab and R. Altenburger, eds. Pesticides in Tropical Agriculture: Hazards and Alternatives, Margraf Verlog, Weikersheim, Germany, pp. 130 - 132.

Scmidt, P., Stiefel, J. and Hurlimann, M. 1997. Extension of complex issues: success factors in integrated pest management, SKAT, p.102.

Shah, P. 1993. Questionnaries: Participatory, Reliable and Interesting?, A note prepared for IIED/IDS Workshop on Alternatives to Questionnarie Surveys, 26 ${ }^{\text {th }}$. October, 1993.

Singh, B.D., Chowdhury, S. and Sujan, D.K. 1993. Perception of field level constraints among the small and marginal farmers of Special Rice Production Programme (SRPP), Proceedings of $10^{\text {th }}$. Indian Science Congress, Goa.

Swaminathan, M.S. 1978. Recent advance in agriculture, Science and Agriculture, Vol. 44, No. 1, p. 227.

Tantray, A.M. and Nanda, R. 1991. Constraints in increasing rice production, Indian Journal of Extension Education, Vol. XXVII, No. $1-2$, pp. $124-128$.

Van de Fliert, E. and Matteson, P.C. 1989. Integrated Pest Control: Channels for Extension in Sri Lanka, Journal of Extension Systems, Vol. 5, June, pp. 33-47.

Yudelman, M., Ratta, A. and Nygaard, D. 1998. Pest Management and Food Production: Looking to the Future, Food, Agriculture and the Environment Discussion Paper 25, International Food Policy Research Institute (IFPRI), Washinton, DC. 